\title{
Spatial distribution of pollen grains and spores in surface sediments of Guanabara Bay, Rio de Janeiro, Brazil
}

\author{
CINTIA F. BARRETO ${ }^{1}$, CLAUDIA G. VILELA $^{2}$, JOSÉ A. BAPTISTA-NETO ${ }^{3}$ and ORTRUD M. BARTH $^{1,4}$ \\ ${ }^{1}$ Laboratório de Palinologia, Departamento de Geologia, Instituto de Geociências, \\ Universidade Federal do Rio de Janeiro, CCMN, Ilha do Fundão, 21941-916 Rio de Janeiro, RJ, Brasil \\ ${ }^{2}$ Laboratório de Geologia Marinha, LAGEMAR, Instituto de Geociências, \\ Universidade Federal Fluminense, Avenida Litorânea, s/n, 24210-340 Niterói, RJ, Brasil \\ ${ }^{3}$ Laboratório de Análise Micropaleontológica, Departamento de Geologia, Instituto de Geociências, \\ Universidade Federal do Rio de Janeiro, CCMN, Ilha do Fundão, 21941-916 Rio de Janeiro, RJ, Brasil \\ ${ }^{4}$ Instituto Oswaldo Cruz, Fiocruz, Avenida Brasil, 4365, 21040-000 Rio de Janeiro, RJ, Brasil
}

Manuscript received on February 25, 2010; accepted for publication on March 1, 2011

\begin{abstract}
Aiming to investigate the deposition of pollen grains and spores in Guanabara Bay, Rio de Janeiro State, 61 surface sediment samples were analyzed. The results showed that the current deposition of palynomorphs in surface sediments of Guanabara Bay represents the regional vegetation of this hydrographic basin. The differential distribution of palynomorphs followed a pattern influenced by bathymetry, tidal currents speed, discharge of numerous rivers, and by human activity. The dominance of representatives of Field Vegetation reflects the changes of the original flora caused by intense human activities in the region. The continued presence and richness of pollen types of rain forest in the samples indicates that their source area might be the vegetation from riparian border of rivers in the western sector of the Bay, where the mangrove vegetation is being preserved. The large amount of damaged palynomorphs may be related to abrasion that occurs during river transport, indicating removal or reworking from their areas of origin.
\end{abstract}

Key words: palynomorphs, surface sediments, deposition, preservation, Guanabara Bay, Brazil.

\section{INTRODUCTION}

Palynological studies are important tools for interpreting the past environments and elucidating questions related to paleoclimates and paleoecology (Ybert et al. 1992, Salgado-Labouriau 2001). However, it is necessary to understand the present environments and the dynamics that controls the deposition of pollen grains and spores before one attempts to interpret the fossil record.

Correspondence to: Cintia Ferreira Barreto

E-mail: cintiapalino@yahoo.com.br
The Palynological analysis of Quaternary sediments has provided important information about the past environment in the coastal region of SE Brazil. Studies have elucidated questions related to sea level oscillation and climate changes as well as to alterations of the natural vegetation as a result of intensive human activities during the Holocene (Toledo et al. 1994, Luz et al. 1999, Barth et al. 2001, 2004, Coelho et al. 1999, Santos et al. 2000). However, pollen studies on surface sediments in lakes and bays that demonstrate the patterns of modern 
pollen deposition and vegetation of this region have not been undertaken to a significant extent. Barreto et al. (2006) presented a palynological analysis of 27 surface sediment samples of Guanabara Bay and reported that the distribution and accumulation of palynomorphs in the bay were influenced by bathymetry, velocity tide and the intensity of fluvial inputs. Studying a lake with tributaries, Luz et al. (2005) verified that fluvial influx, wind action and lakes bathymetry influenced the spatial distribution of pollen grains, spores and algae; an additional control was palynomorph size. Toledo et al. (1994) verified that the deposition of palynomorphs was influenced by the bathymetry and wind direction in a lagoon without any tributaries in the northeastern region of the state of Rio de Janeiro.

It is necessary to understand the processes that control the preservation, transport and deposition of pollen grains and spores in aquatic environment in order to obtain an accurate interpretation of pollen occurrence. The present study offers a better resolution of environmental questions related to modern ecosystems and characterizes the processes of current dynamics that control the deposition and preservation of palynomorphs in distinct sectors of the Guanabara Bay, indicating the best areas to collect sediment cores for future palynological studies.

\section{STUDY AREA}

The Guanabara Bay is located in the coastal area of Rio de Janeiro State - Southeast Brazil, between $22^{\circ} 40^{\prime}-23^{\circ} 00^{\prime} \mathrm{S}$ of latitude and $043^{\circ} 00^{\prime}-043^{\circ} 20^{\prime} \mathrm{W}$ of longitude (Figure 1). It lies within a depressed and elongated tectonic band of Tertiary age known as "Baixada Fluminense" or Guanabara Rift, of the halfgraben type (Ruellan 1974, Ferrari 1990, Amador 1997). Its origin is also related to climatic and sea level changes that occurred during the Quaternary and that resulted in the drowning of a Pleistocene fluvial valley (Amador and Ponzi 1974, Ireland 1987, Amador 1992, 1997, Martin et al. 1997).
The Guanabara Bay extends in the SO-NE direction, reaching a maximal width of $28 \mathrm{~km}$ and a perimeter of $131 \mathrm{~km}$; it possesses a narrow entrance of approximately $1.6 \mathrm{~km}$ width. The bay surface area, excluding its islands, currently measures $372 \mathrm{~km}^{2}$. Its hydrographic basin covers approximately $4,600 \mathrm{~km}^{2}$ and includes the metropolitan regions of the cities of Rio de Janeiro, Duque de Caxias, Niterói and São Gonçalo. There are 45 rivers that discharge in the bay, the Macacu and Caceribu being the most important ones (Amador 1997, Kjerfve et al. 1997). The Guanabara Bay tides are classified as semidiurnal, with one complete tidal cycle of about 12.5 hours (Amador 1997).

The bathymetry of the Guanabara Bay is influenced mainly by the tides. The narrow entrance of the bay is occupied by a big sandy bank that extends upwards from the bay floor to a height of 12 $\mathrm{m}$. This bank promotes the channelization of water flow and is also an obstacle to the tidal circulation. The central channel of the bay has a S-N orientation starting at the bay entrance until the Governador Island and accounts for the deep depths in the bay (around 30 and $40 \mathrm{~m}$ deep). The dominant sediments in the channel are medium to very fine sands. The innermost part of the bay (i.e., the north region) has smooth, flat bathymetry (less than $10 \mathrm{~m}$ ) and a high sedimentation rate. Its sediments are primarily silt/clay (Amador 1992, 1997, Dias and Quaresma 1996, V.S. Quaresma, unpublished data, Kjerfve et al. 1997, L.F. Catanzaro unpublished data).

The climate of the Guanabara Bay region is tropical humid with a well - defined rainy season between December and April, and a dry season between June and August (Denemet 1992). The mean annual air temperature is $23.7^{\circ} \mathrm{C}$, and the mean annual relative humidity is $78 \%$, with an annual average precipitation higher than 2,000 $\mathrm{mm}$ over the Serra do Mar hills, and 1,000 to 1,500 $\mathrm{mm}$ in the lowlands (Baixada Fluminense region) (Amador 1997). The winds most frequently blow from the east (21\% of the time), south (17\%) and 


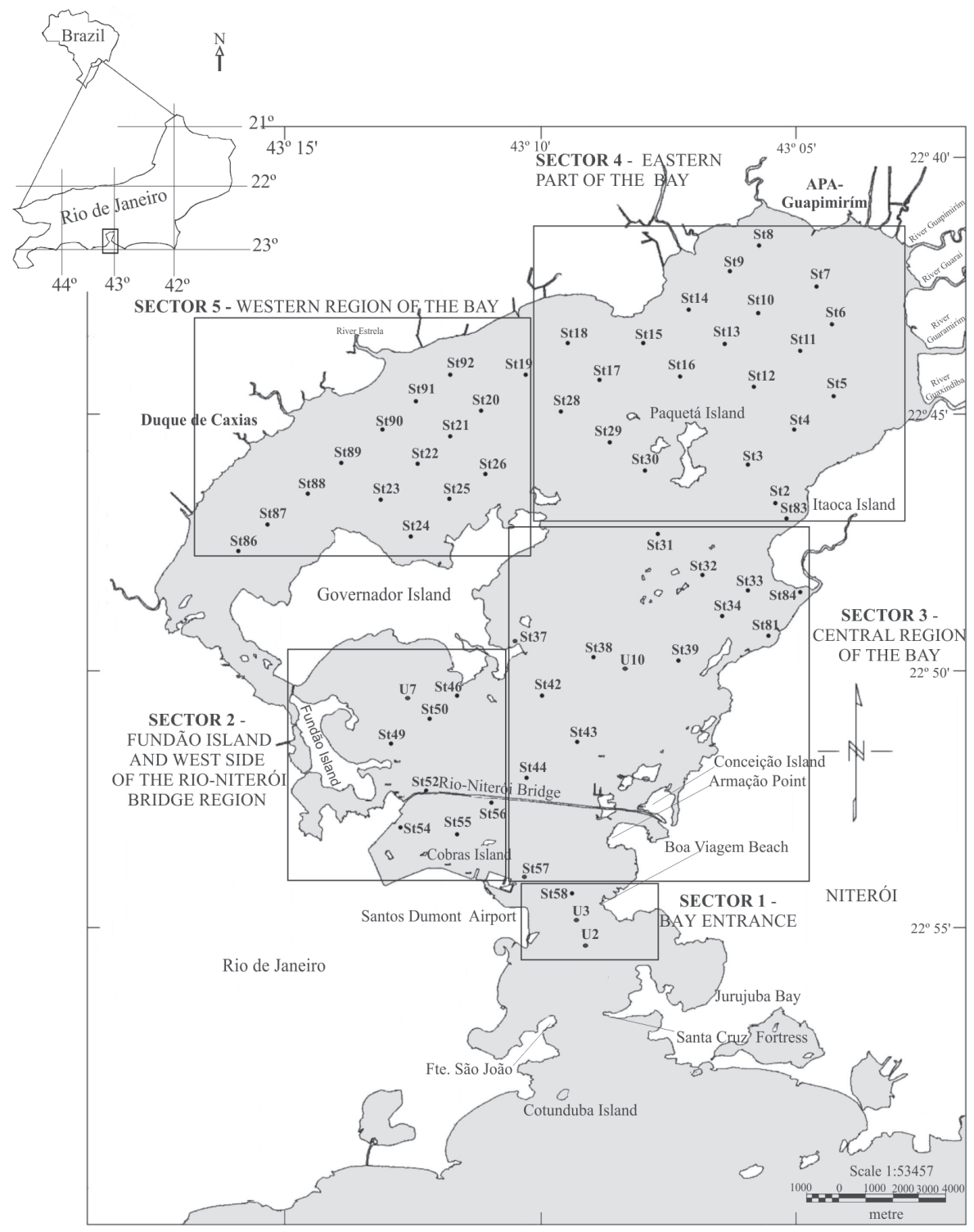

Figure 1 - Map of the study area showing the location of the surface sediment samples and the different sectors of the Guanabara Bay (Vilela et al. 2003).

north (14\%), with a mean velocity of $3 \mathrm{~m} / \mathrm{s}$ in the Santos Dumont Airport area (Kjerfve et al. 1997).

A Tropical Rain Forest (Mata Atlântica) is considered as one of the richest ecosystems. This vegetation is preserved mainly in forest reserves and on the mountain slopes (Radambrasil 1983, Veloso et al. 1991). According to Veloso et al. (1991) vegetation types such as Ombrophilous Forest ("Floresta Ombrófila"), Mountain Forest ("Floresta Montana") and Field Vegetation ("Vegetação Campestre") were recognized in the area. A phytosociological survey conducted by Guedes(1988) in the Magé municipality, $15 \mathrm{~km}$ away from the Guanabara Bay, recorded the following predominant plant associations: an herbaceous stratum of Aphelandra (Acanthaceae), Dorstenia (Moraceae), Heliconia (Heliconiaceae), Olyra (Poaceae), Pfaffia (Amaranthaceae) and Polygala (Polygalaceae); a shrub stratum of Eugenia (Myrtaceae), Faramea (Rubiaceae), Miconia (Melastomataceae), Myrcia (Myrtaceae), Ouratea 
(Ochnaceae), Psychotria (Rubiaceae) and Rudgea (Rubiaceae); and an arboreal stratum of Aniba (Lauraceae), Aparisthimium (Euphorbiaceae), Euterpe (Arecaceae), Guapira (Nyctaginaceae), Guarea (Meliaceae), Newtonia (Leguminosae-Mimosoidea), Pera (Euphorbiaceae), Sebastiania (Euphorbiaceae) and Tapirira (Anacardiaceae).

The Mangrove vegetation occurs in the innermost part of the bay, mainly in the environmental protection area (APA) of Guapimirim, and bears both arboreal and herbaceous physiognomies. Predominant plants recorded are Acrostichum (Pteridaceae), Avicennia (Verbenaceae), Cecropia (Moraceae), Clytostoma (Bignoniaceae), Crenium, Dalbergia(Fabaceae),Eichhornia(Pontederiaceae), Hibiscus (Malvaceae), Laguncularia (Combretaceae), Loranthaceae, Arecaceae, Paspalum (Poaceae), Passiflora (Passifloraceae), Pistia (Araceae), Rhizophora (Rhizophoraceae), Surpus, Poaceae, Tabebuia (Bignoniaceae) and Typha (Typhaceae) (Araújo and Maciel 1979).

\section{MATERIALS AND METHODS}

\section{FIELD WORK}

In order to examine the patterns of palynomorph deposition across different areas of the Guanabara Bay, a total of 61 surface sediment samples were collected using a "Van-Veen"collector sampler. The samples were grouped into five sectors (Vilela et al. 2003) (Figure 1). Three samples were obtained in the sector next to the bay entrance and were composed of medium to fine sand. Thirteen samples were collected in the central sector, consisting of fine sand. The Fundão Island sector comprised eight samples of silty clay and argillaceous silt sediments, while fifteen samples were collected in the western sector and were also dominated by argillaceous silt. Twenty one samples, composed of muddy sediment with a predominance of clay, were collected in the eastern sector (Catanzaro unpublished data).
LABORATORY ANALYSIS

The samples were chemically treated according to the standard methodology for Quaternary sediments proposed by Ybert et al. (1992). This includes the use of $10 \%$ of $\mathrm{HCl}$ for the elimination of carbonates, followed by $40 \% \mathrm{HF}$ for elimination of silicates, then the acetolysis and heavy liquid separation using a ZnCL2 (density = 2). To estimate the concentration of palynomorphs per volume of sediment, two tablets of exotic Lycopodium clavatum spores (about 11,670 spores per tablet) were introduced into each sample prior to processing (Stockmarr 1971). A minimum of three slides was prepared for each sample, and at least 200 pollen grains per sample were counted at 400x magnification.

The Pollen identification was based upon pollen catalogues (Barth 1972, 1976, Barth and Barbosa 1972, 1975, Bove and Barth 1992, Barth and Costa 1993, Luz and Barth 2000, Hooghiemstra 1984, D.W. Roubik and J.E.P. Moreno, unpublished data) and specific papers (Behling 1995, Garcia 1997, 1998, Lorscheitter et al. 1998, 1999). In general, pollen types were identified at family or generic levels.

Palynomorph counts were expressed as relative abundance (percent) and concentration. The percentage calculation was based upon the total sum of pollen grains (herbs, shrubs and trees), excluding algae and fern spores. The software Tilia and Tiliagraph (Grimm 1987) were used for the statistical analysis of the palynological data. The identified palynomorphs were grouped into the respective vegetation types according to Veloso et al. (1991).

Deteriorated pollen grains and spores were analyzed according to Moore et al. (1991).

\section{RESULTS}

One hundred thirty-one palynomorph types were identified in the 61 surface sediment samples analyzed. Grassland pollen grains dominated the assemblages, showing high percentages in almost all the samples (more than 66\% in sample St16; Figure 2). Poaceae 
was the dominant pollen type (more than $50 \%$ in samples U2, U10, St37, St16 and St24), followed by Brassica (11\% in sample St56), Amaranthus/ Chenopodiaceae (9\% in sample St85) and Borreria densiflora (3\% in sample St50; Figure 3). Alchornea, Arecaceae, Celtis, Hedyosmum, Lecythis, Rapanea and Trema were the most im-portant pollen types of the Ombrophilous Forest vegetation (Figure 3). This vegetation presented a great richness of pollen types (55 pollen types), and high percentages in samples St58, St55, St44, St39, St84, St31, St4, St6 and St14 (more than 35\%; Figures 2 and 3). Three pollen types, Drimys brasilienses, Podocarpus and Podocarpus lambertii, belonging to the Montane Forest vegetation type, could be identified, with Podocarpus lambertii being the most important one (Figure 4). Pollen grains of Cyperaceae, Scrophulariaceae and Typha (Hygrophilous assemblage) were observed in all the analyzed samples, with percentages less than 10\% (Figure 4). Avicennia and Rhizophora of the Mangrove vegetation were found in the St50 sample located near the APA of Guapimirim (Figure 4). Asteraceae, Euphorbiaceae, Fabaceae, Melastomataceae/Combretaceae, Myrtaceae and Solanaceae were classified as Wide distribution taxa (Figure 4).

PALYNOLOGICAL ANALYSIS IN DIFFERENT SECTORS OF THE GUANABARA BAY

\section{Bay entrance sector}

Three samples were analyzed, and 47 pollen types from the total of 96 pollen types were identified. The pollen of Grassland predominated in two samples taken near the bay entrance (maximum of $56 \%$ in samples U2 and U3). The lowest pollen percentage of this group was observed in the most northerly sample, St58 (31\%; Figure 2). Poaceae was the most important pollen type of Grassland $(55 \%$ in sample U2), and additional pollen types such as Amaranthus/Chenopodiaceae, Borreria densiflora and Chamaesyce were recorded in very low percentages (Figure 3). The highest percentage of Ombrophilous Forest pollen occurred in sample St58 (31\%), and it diminished to $12 \%$ near the entrance of the bay (sample U2; Figure 2). Alchornea, Arecaceae, Casearia, Celtis, Cupania, Hedyosmum, Ilex, Lecythidaceae, Rapanea, Sebastiania and Trema were the most important of Ombrophilous Forest pollen types (Figure 3). Montane Forest pollen types were recorded in only one sample with a very low percentage (sample St58 with less than 5\%; Figure 2). Pollen types of the Mangrove vegetation, as well as algae, did not appear in samples of this sector (Figure 2). Hydrophyte pollen types presented a low percentage (less than $5 \%$ ), and the highest percentage of exotic genera (more than $16 \%$ in samples U3) and fern spores (sample U3 with more than 59\%) was observed in this section (Figure 2).

The lowest pollen grain and spore concentration was observed in this sector, with less than 4,500 palynomorphs/g in sample St58 and less than 1,500 in samples U2 and U3 (Figure 5).

\section{Fundão island sector}

Sixty-two pollen and spore types were identified in eight samples analyzed. The dominant Grassland taxa occurred in $90 \%$ of the samples (more than $50 \%$ in sample St52; Figure 2). Poaceae presented the highest percentages (more than $25 \%$ in all samples), followed by Amaranthus/Chenopodiaceae (maximum of 9\% in sample St52), Brassica (more than 5\% in all samples) and Borreria densiflora and Chamaesyce (percentages usually less than 5\%; Figure 3). The highest percentages of Ombrophilous Forest pollen types occurred south of the Rio-Niterói Bridge, near its western end (sample St55 with 40\%; Figure 2). Arecaceae, Celtis, Lecythidaceae, Rapanea and Trema contributed to the increase of percentages of the Ombrophilous Forest pollen type in sample St55 (Figure 3). Montane Forest plant taxa of low percentage (less than 5\%) were recorded 
in five samples (Figure 2). Pollen types representing the Mangrove vegetation were not observed in this sector (Figure 2), and Hygrophyte pollen presented low percentages in all samples (about 5\%), with some increase in sampleSt55 (11\%; Figure 2). Exotic genera were recorded in samples near the margins of Governador and Fundão Islands (samples St52, St49, St50 and St46), and in one sample collected near Rio-Niterói Bridge (sample St56, less than 9\%; Figure 2). Fern spore percentages ranged between 5 and $40 \%$ in all samples (Figure 2).

The highest concentration of pollen grains and spores was observed in samples next to the Fundão Island (samples St49 - 14,500 and U7 - 17,000 palynomorphs/g) and in a sample between RioNiterói Bridge and the Cobras Island (sample St55, more than 4,500 palynomorphs/g). The other five samples presented in general low concentration values (less than 1,000 palynomorphs/g) (Figure 4).

\section{Central sector of the bay}

Eighty-eight pollen and spore types were identified in 14 samples analyzed from this area. The Grassland taxa dominated in almost all samples (more than 50\% in sample U10; Figure 2). Poaceae percentage was the greatest (more than $15 \%$ in all samples), followed by Amaranthus/ Chenopodiaceae (maximum of 9\% in sample St85) and Borreria densiflora; Brassica occurred in more than $70 \%$ of these samples, with abundances usually less than $10 \%$ (Figure 3). High percentages of Ombrophilous Forest pollen occurred in samples St44, St42, St39, St84 and St31 (more than 40\% in sample St31; Figure 2). Alchornea, Arecaceae, Celtis, Hedyosmum, Lecythis, Rapanea and Trema presented their highest percentages. Other Ombrophilous Forest taxa, such as Anadenanthera, Lecythidaceae and Piper, were recorded in very low percentages (less than 6\%; Figure 3). Podocarpus lambertii was the most common Montane Forest pollen type, with less than 3\% (Figure 3). Mangrove taxa appeared ) near the southeastern margin of the bay, close to rivers, but represented less than $1 \%$ of the pollen sum (samples St34, St85 and St84; Figure 2). Rhizophora was the most common Mangrove pollen type. Hydrophyte plants presented low percentages (1 - 9\%; Figure 2). The highest percentage of fern spores was recorded in a sample south of Rio-Niterói Bridge (sample St57), and a very low percentage occurred near the southeast margin (sample St84, less than 5\%). Other samples frequently contained $60 \%$ spores (Figure 2 ).

The sediments of the main canal south of Rio-Niterói Bridge (sample St57) and eastward the Governador Island (samples St44, St43, St42, U10 and St38) showed a low concentration of pollen grains and spores (less than 11,000 palynomorphs/g). Low concentration were also observed in samples St32 and St84 (less than 10,000 pollen grains/g of sediment). An increase of pollen grain concentration was observed only in the east margin of the bay near São Gonçalo city, with more than 18,000 palynomorphs/g (Figure 4).

EASTERN SECTOR OF THE INNERMOST PART OF THE BAY, IN THE VICINITY REGION OF PAQUETÁ ISLAND AND IN THE APA OF GUAPIMIRIM

Ninety-seven of the 129 pollen grains and spore types were identified in the 21 samples analyzed from this area. Pollen types of Grassland predominated in almost all samples (more than 35\%; Figure 2). Poaceae was the most important (20\% to 70\%), followed by Amaranthus/Chenopodiaceae ( $1 \%$ to $9 \%)$, Borreria densiflora (1\% to $3 \%)$ and Chamaesyce ( $1 \%$ to $4.5 \%$; Figure 3 ). The Ombrophilous Forest vegetation taxa presented the highest richness of pollen types (53 pollen types). The highest percentage of this group occurred in the northern margin near the rivers in the APA of Guapimirim area; abundances varied between 35 and $40 \%$ in samples St4, St5, St9 and St14 (Figure 2). Alchornea, Arecaceae, Cecropia, Celtis, 
Hedyosmum, Lecythidaceae, Lecythis, Phyllanthus, Rapanea and Trema occurred in more than 50\% of these samples (Figure 3). Montane Forest taxa presented lower percentages $(1 \%-6 \%$; Figure 2$)$. Mangrove taxa were observed in samples located near the mangrove of the APA of Guapimirim and the northern margin of the bay, but with less than $5 \%$ relative abundance in seven samples (samples St83, St3, St5, St6, St10, St11 and St14; Figure 2). Rhizophora was the most common Mangrove pollen type (less than 5\%), and Cyperaceae, Scoparia and Typha were the dominant Hydrophyte pollen types, though their percentages were less than $9.5 \%$ (Figure 4). Fern spore percentages were practically in all samples (Figure 2).

Three samples in this area (samples St9, St14 and St18) presented the highest pollen grain and spore concentration observed in the Guanabara Bay. The highest pollen concentration occurred next to the river inflows in the north margin of the bay (from more than 30,000 palynomorphs/g to a maximum of 49,199 palynomorphs/g). It decreased eastwards of the Paquetá Island (less than 12,000 pollen grains/g in samples St15, St16, St17, St28, St29 and St30) and in one sample of the northeastern margin near the Itaoca Island (less than 10,000 palynomorphs/g in samples St83). In the northeastern margin, near the APA of Guapimirim, approximately 20,000 palynomorphs/g (samples St2, St3, St4, St5, St6, St7, St8, St10, St11, St12 and St131) were observed (Figure 4).

WESTERN SECTOR OF THE INNERMOST PART OF THE BAY, NORTH OF GOVERNADOR ISLAND

Fifteen samples contained 86 types of pollen and spores identified. The highest percentage of the Grassland taxa (47\%) was recorded in samples reco-vered near the Governador Island (samples St23, St24 and St25; Figure 2). Poaceae (more than $25 \%$ in all samples) and Amaranthus/ Chenopodiaceae (1\% to $3.5 \%)$ were the most abundant taxa of this group (Figure 3). Pollen types of the Ombrophilous Forest also occurred (more than $10 \%$ in all samples); the highest percentages were observed in samples St19 (38\%), St20 (33\%) and in a sample collected near the mouth of Estrela river (sample St91, 36\%; Figure 2). Alchornea, Anadenanthera, Arecaceae, Celtis, Hedyosmum, Lecythidaceae, Lecythis, Rapanea and Trema occurred in more than $50 \%$ of samples (Figure 3). Montanee forest taxa occurred in samples collected near the Governador Island (samples St20, St21, St22, St24, St25 and St26) and in one sample located next to the northwest margin of the bay; the abundance in each sample was less than 5\% (Figure 2). Representative pollen types of the Mangrove vegetation were not observed in these samples. Among Hygrophytes, Cyperaceae, Typha and Scrophulariaceae presented less than 5\% (Figure 4). The alga Botryococcus was observed in low abundance (less than 1\%) in samples St20, St25, St92, St91 and St88 (Figure 4 ), and fern spores presented a significantly reduced frequency (Figure 2).

Except for St87, all six out of seven samples located near the northwest margin of the bay presented a high concentration of pollen grains and spores (samples St92, St91, St90, St89, St88 and St86). In two of these samples the highest concentration of pollen was more than 24,000 pollen grains/g of sediment. In an area located north of the Governador Island, the pollen concentration of sample St21 was 25,000 pollen grains/g, and there was a significant decrease near the rocks of the Governador Island (less than 7,500 pollen grains/g, samples St23 and St24) (Figure 5).

Spatial Distribution of Degraded Palynomorphs IN THE SURFACE SEDIMENTS OF THE GUANABARA BAY

Most pollen and spores presented well preserved exines (in more than $50 \%$ of all samples). 




Figure 2 - Percentage palynodiagram of the ecological groups recognized in the surface sediment samples of the Guanabara Bay. 


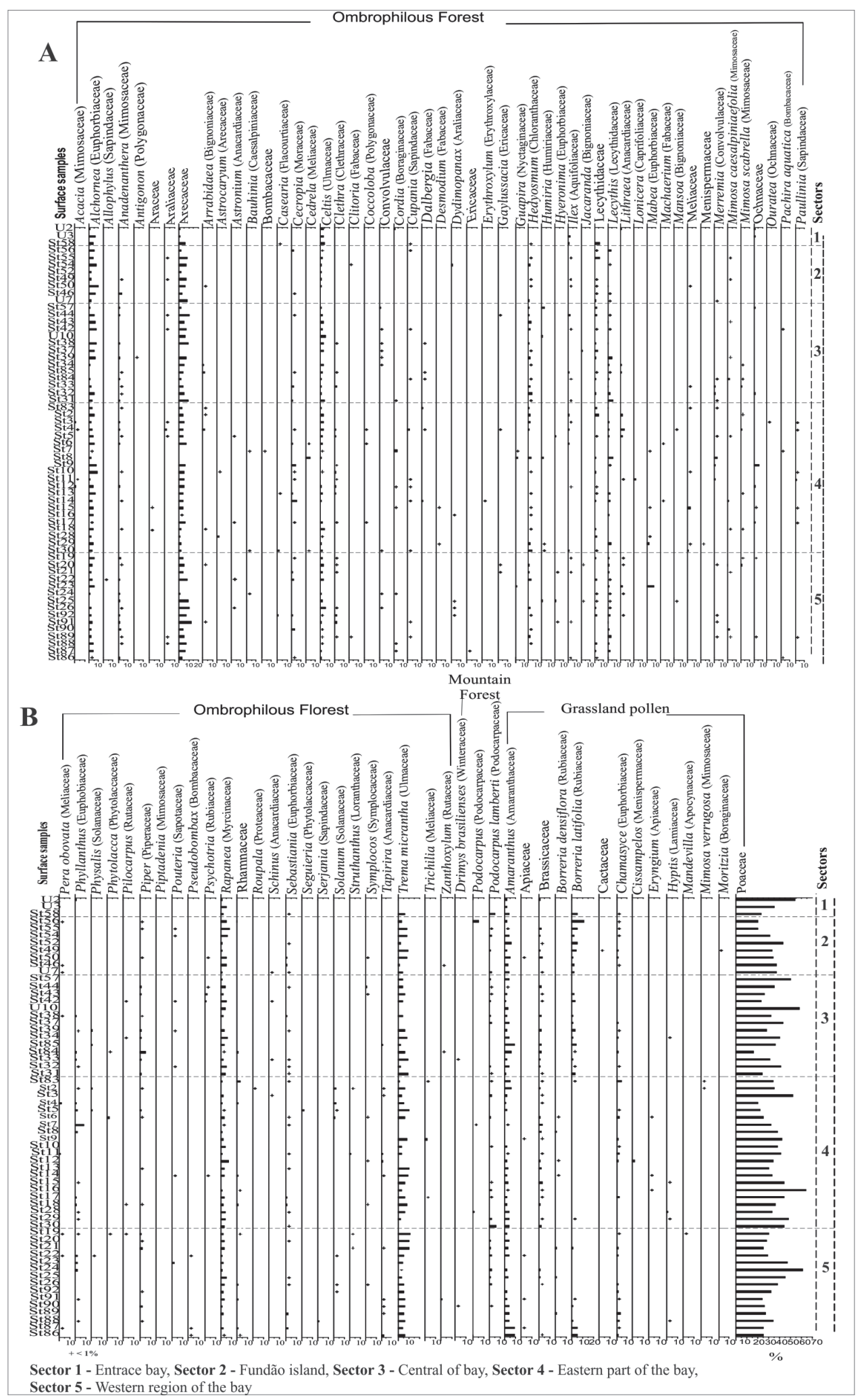

Figure 3 - Percentage palynodiagram of the pollen types grouped into the (A) Dense Ombrophilous Forest vegetation, (B) Montane Forest and Grassland Pollen. 

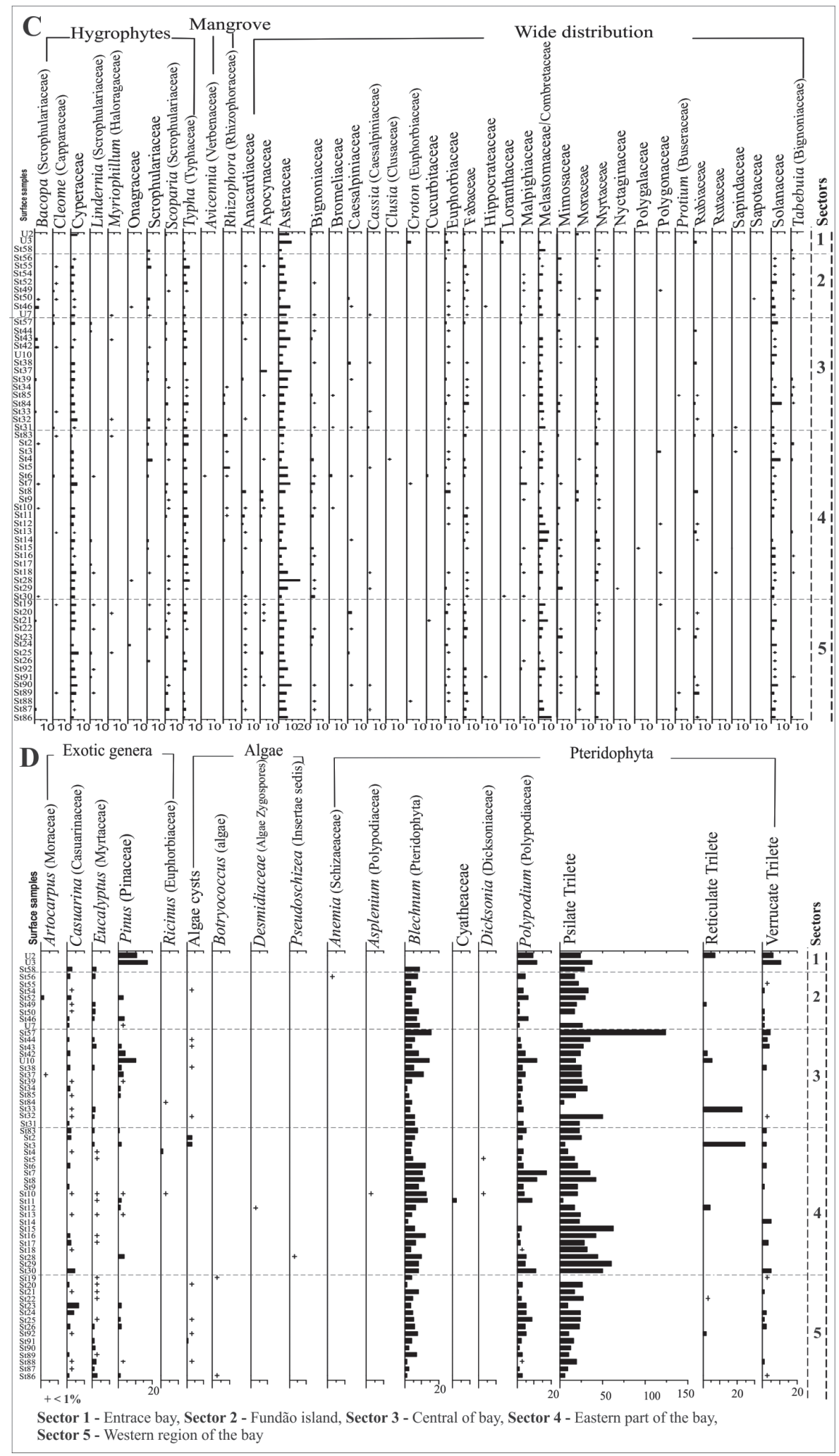

Figure 4 - Percentage palynodiagram of the pollen types grouped into the (C) Hygrophytes, Mangrove, Wide distribution, (D) Exotic genera, Algae and Pteridophyta. 


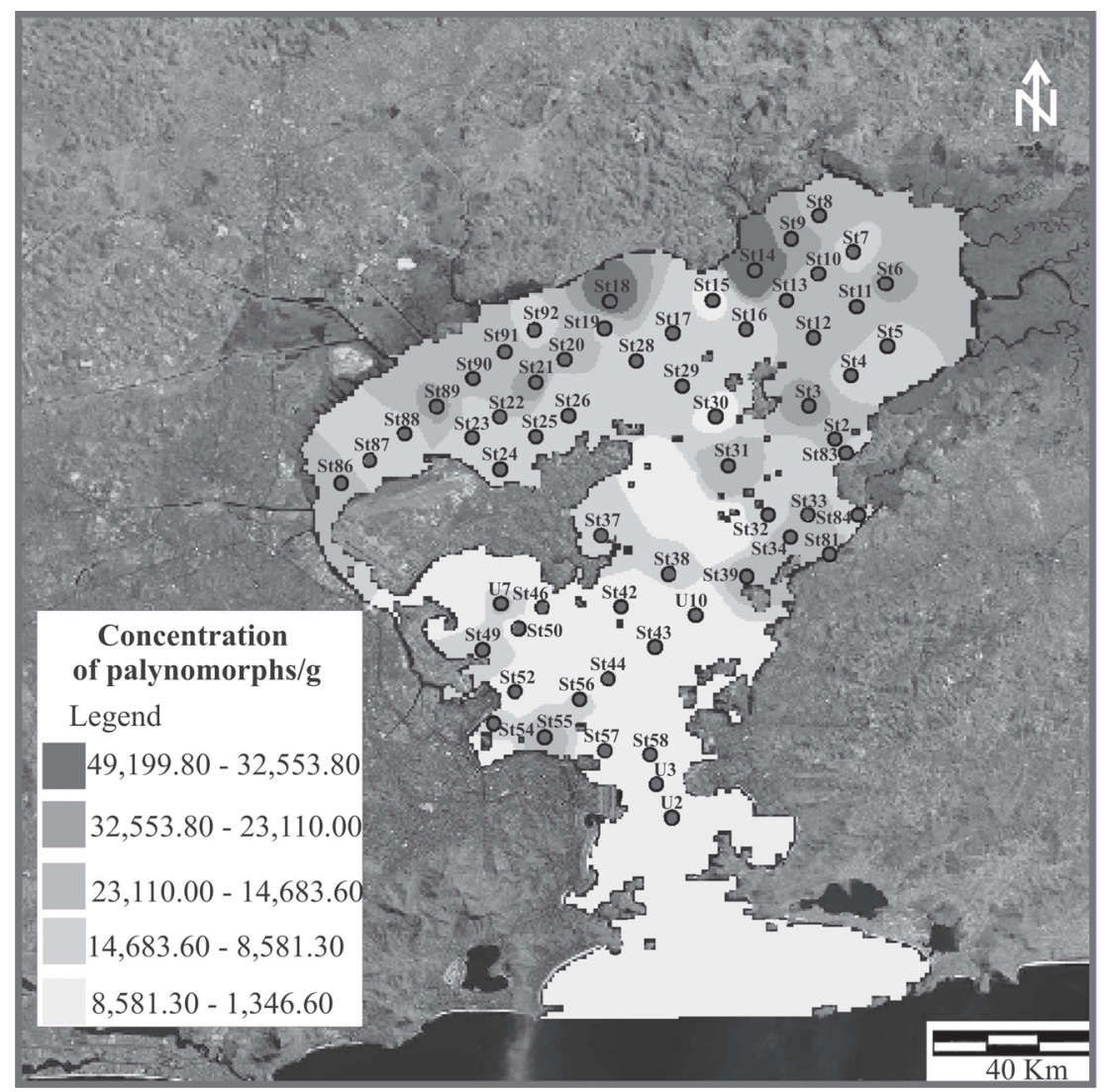

Figure 5 - Map of total concentration of palynomorphs/g observed in surface sediment samples of the Guanabara Bay.

Mechanical damage to palynomorphs was more frequent than corrosion and degradation. The highest level of deterioration was recorded in sample U3, located near in the entrance of the bay between Boa Viagem Beach and Santos Dumont Airport; more than $43 \%$ of palynomorphs exhibited damage. In sample St54, near the Fundão Island, more than $30 \%$ of palynomorphs showed signs of degradation, particularly samples St57 and St39 in the vicinity of the main channel. An increase of pollen grains presenting corrosion was observed in samples St37, St39 and St33, with the highest percentage in the eastern sector of the bay of about 10\% (samples St5, St6, St7, St10 and St11). The western sector of the bay produced samples with the highest percentage of damaged palynomorphs (samples St21 (37\%) and St26 (35\%)). The damage degree decreased towards the bay margin (less than 10\%; Figure 6).

\section{DISCUSSION}

Palynological Analysis/Regional Vegetation

The palynological analyses carried out in the surface sediments showed that the pollen and spores deposition represented the integration of pollen types from a large source area, which corresponds to the Atlantic Forest vegetation (located on the mountain slopes and in forest reserves) and the openland plants and results from large deforested areas by intense human activities. The large area of the Guanabara Bay drainage basin (about $4.600 \mathrm{~km}^{2}$ ) and the existence of many fluvial influxes (more than 40) provide a pollen signal of the regional vegetation as suggested by several studies that have demonstrated the relationship between the size of the catchment and the way in which pollen records reflect vegetational cover (Jackson 1990, Sugita 1993, Stebich et al. 2005). 


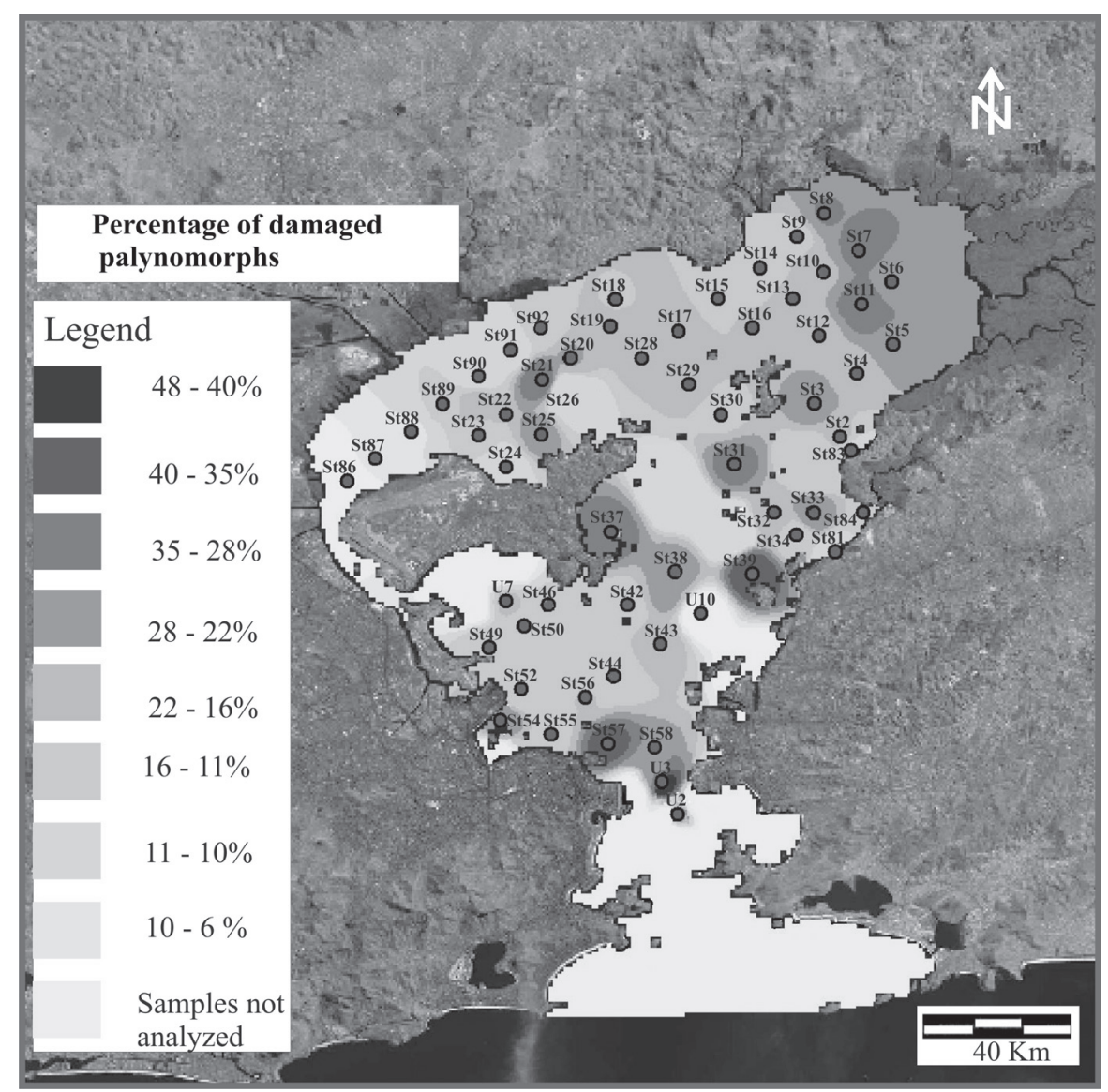

Figure 6 - Map of percentage of damages palynomorphs observed in surface sediment samples of the Guanabara Bay.

According to Jacobson and Bradshaw (1981), in a large aquatic environment, the pollen assemblage tends to be influenced by regional elements, while the majority of pollen grains deposited in smaller basins is dominated by those originated from local elements. Bennett (1986) suggested that most pollen grains arriving at a basin are carried by current water channels than by wind, as it was observed in the present study. Nevertheless, pollen analysis of surface sediments in the Lagoa Salgada, north of Rio de Janeiro State, showed a strong influence of the wind direction in the pollen grain deposition (Toledo et al. 1994).

Herbaceous pollen is prevalent in the Guanabara Bay pollen assemblages. Poacea was the dominant pollen type of the Grassland, followed by Brassica, Amaranthus/Chenopodiaceae, Borreria densiflora and Chamaesyce (Figure 3). Inside the Fundão Island sector, as well as in the western sector, north of the Governador Island, the dominance of Grassland taxa was observed in $90 \%$ of the samples analyzed. This reflects the modern vegetation along the island (Fundão and Governador) margins. These plants were observed mainly in degraded areas of the bay and in river margins as well (Radambrasil 1983, Veloso et al. 1991, Amador 1997) (Figure 3). The northwest area of the Guanabara Bay is considered the most degraded area, receiving discharges from the most the polluted rivers of the bay (Baptista Neto et al. 2006), and presenting the lowest pollen grain input.

The largest enrichment and high values of the regional pollen types from the Ombrophilous Forest vegetation were observed mainly in sediments close 
to the rivers from the APA of Guapimirim (eastern sector of the bay) and in the northern bay margin. In the western sector of the innermost part of the bay, north of the Governador Island, the Ombrophilous Forest pollen types also occurred (more than $10 \%$ in all samples); Alchornea, Anadenathera, Arecaceae, Celtis, Hedyosmum, Lecythidaceae, Lecythis, Rapanea and Trema were the most important ones. In accordance to Veloso et al. (1991), Alchornea, Arecaceae, Celtis, Hedyosmum, Meliaceae and Trema are significant trees of the Ombrophilous Forest vegetation growing in the low landscapes of Rio do Janeiro State.

Podocarpus lambertii, a species of the Montane Forest, was best represented at unique sample close to the northwestern margin of the bay (Figure 3). In accordance to Veloso et al. (1991) and Radambrasil (1983), this pollen type characterizes the vegetation of the Ombrophilous Dense Montane Forest located in the mountain hillsides.

Cyperaceae, Scrophulariaceae and Typha were the most important Hydrophyte pollen types. The increase of their percentages in samples near the APA of Guapimirim (Figure 4) may be associated to plants from flooded margins of rivers discharging into this sector of the bay (Araújo and Maciel 1979). The mangrove taxa recorded only in the samples of the southern bay margin in the central and eastern sector of the innermost part of the bay can be associated mainly with the proximity of the mangrove of the APA of Guapimirim. Rhizophora was the most common mangrove pollen type and a high pollen producer, while Avicennia is a low pollen producer, considering that Rhizophora is wind pollinated whereas Avicennia is insect pollinated. According to Jackson (1990), pollen grains dispersed by animals tend to be deposited next to the plant source and are not adapted to dispersion by the wind. Barreto et al. (2007) and Barth et al. (2004) studied Holocene sediments of a core located next to the Island of Paquetá (from about $8 \mathrm{~km}$ of the Guapimirim mangrove forest), where the presence of pollen types indicating mangrove in the sediment level of 4.210 years A.P. ago was not recorded. By analyzing a sediment core collected in the northeast portion of the bay next to the APA of Guapimirim, São-Thiago (2005) evidenced a composed floristic scenery for a dense mangrove and river bordering forest vegetation of the domain of Tropical Rainforest.

The largest percentages of exotic genera were observed mainly within the sector of the Bay entrance and in the Fundão Island. These regions were highly impacted by human activities. The Pinus pollen, which is an exotic genera, was more common, since it was used for the reforestation of the same areas of the Guanabara Bay highlighting the human activities in the region (Veloso et al. 1991) (Figure 4). Fern spores concentration was practically constant in all samples of this sector (Figure 5). The presence of Botryococcus (Algae) indicates the proximity of a freshwater source (Guy-Ohlson 1992) ( Figure 4).

The obtained pollen data represented very well the regional vegetation, and different pollen assemblages were observed in different bay sectors. Therefore, it was necessary to analyze separately each sector in order to a better understanding of the pattern distribution of palynomorphs in the bay sediments.

\section{Spatial Distribution of Pollen Grains AND Spores}

The variability of the pollen spectra in the sediments of different sectors of the Guanabara Bay reflects the hydrodynamic and bathymetryc characteristics and changes in the vegetation surrounding the bay (Sugita 1993, Traverse 1994, DeBusk 1997). The pollen spectra of samples from the bay entrance sector presented the lowest pollen grain and spore concentration (Figure 5). This may be explained by the increase of the tidal water speed due mainly to the narrow bay entrance and its bathymetry that does not the palynomorphs deposition, and induce its transport into the most internal sectors, in the $\mathrm{S}-\mathrm{N}$ direction. The greatest values of tide speed 
occur in this sector, near the Gragoatá Fort and the Santos Dumont Airport (Kjerfve et al. 1997).

A low increase in the concentration values of pollen grains and spores was observed in samples taken next to the Fundão Island (samples St49 and U7) and in a sample between Rio-Niterói Bridge and the Cobras Island (Figure 5). It was due mainly to the low current energy in this area. The geomorphologic strait in the northwest portion of the Governador Island contributed to an increase in the tide current speed, even when dominated by low energy (Amador 1997). It possibly promoted the remobilization of palynomorphs previously deposited in other areas of this sector. According to Wilmshurst and McGlone (2005), lake sediment sources can include the inwash of secondary pollen and spores of mixed ages from eroded soils, river bank sediments and littoral sediments, as well as contemporaneous pollen and spores from aerial deposition, rain-out, surface runoff and inwash of debris from the catchment. The low concentration values of palynomorphs in these samples was related to the poorly covered areas of vegetation of the Governador and Fundão Islands, and next to Praça XV, which is highly impacted by the urban development.

The current intensity and deep depth in the main channel south of Rio-Niterói Bridge (sample St57) and east of the Governador Island (samples St44, St43, St42, U10 and St38) may be responsible for the low concentration of pollen and spores (Figure 5 ). The intensity of the current in the main channel of the bay decreases the accumulation of pollens in this sector, and allow the deposition of pollens in others areas of the bay. In these sectors an increase of pollen grain concentration was observed only in the east bay margin near to São Gonçalo city, where water current speed was reduced by the widening of the bay in alignment with Santos Dumont Airport Gragoatá rocky coastal area (JICA 1994).

In the eastern sector of the innermost part of the bay, three samples presented the highest pollen and spore concentrations observed in the Guanabara Bay, with the maximal pollen concentration occurring next to the river mouths at the north margin of the bay (Figure 5). The ease of palynomorphs deposition in this area can be associated to the low energy level of water flows and the flat bathymetry, which result in mud sedimentation with the predominance of clay (Kjerfve et al. 1997, Amador 1997, L.F. Catanzaro, unpublished data). With the exception of sample St87, all six samples located near the northwest margin of the bay presented high concentrations of pollen and spores. This may be associated to the low water energy and the flat bathymetry (Kjerfve et al. 1997, Amador 1997, L.F. Catanzaro, unpublished data). Numerous tributaries discharge into this sector, and contribute to the strong deposition of pollen grains and spores.

\section{DifFERENTIAL PRESERVATION OF PALYNOMORPHS}

Pollen grains and spores preservation was generally excellent in surface sediment samples of the bay. An abundance of damages observed may be related to collisions occurring during the fluvial transport of palynomorphs, which indicates a removal from its source area (Tyson 1995). In accordance to Campbell (1991), pollen grains and spores damaged by erosion were found in many sedimentary basins and can be interpreted as a result of a new deposition after a period of exposition to the air, including cycles of humid and dry climates.

A high level of deterioration recorded in one sample located in the bay entrance, between Boa Viagem Beach and Santos Dumont Airport (sample U3), may be due mainly to the high energy of transport of different types of sediment, causing the rupture of pollen and spore exines. The geomorphology at northwest of the Governador Island contributes to an increase in the current speed of tides, promoting the remobilization of palynomorphs previously deposited in other areas of this sector. This fact may explain the high percentage of palynomorphs exhibiting damages observed in sample St54. On the other hand, in the 
sector of the main channel, the highest percentages of deterioration were observed in samples St57 and St39. The increase of deposition of corroded pollen grains and spores was observed in samples St37, St39 and St33, indicating the exposition to the air. Following Wilmshurst and McGlone (2005), the process of corrosion must therefore occur some time after the pollen grains and spores were released from the source vegetation. In the eastern sector, in most parts of the bay, the high percentage of corroded palynomorphs observed in samples St5, St6, St7, St10 and St11 may be related to an intense action of microorganisms present in the mangrove. In the innermost samples of the eastern region in the bay, the maximal percentage of mechanical damages appeared in samples St21 and St26, decreasing towards the bay entrance. This pattern may be due to both tide currents and river inflows (Figure 6).

\section{CONCLUSION}

In summary, the patterns of modern pollen deposition in the Guanabara Bay surface sediments represent the regional vegetation of this hydrographic basin. Irregular spatial distribution of palynomorphs is related to the bay bathimery, the tide currents, the inflow of numerous rivers and human perturbation. The dominance of grassland taxa reflects the wideranging areas of human occupation. The presence of Ombrophylous Forest pollen grains in all analyzed samples should confirm the presence of forest segments in the low-lands, as well as the hillside and Montane Forest preservation. The damaged pollen grains and spores may be related to abrasion occurring during their fluvial transport, indicating removal and reworking from their source areas.

The presentresults also contribute to a predictive model for the core samples analysis, improving comparison of Recent and Holocene results, which are very important for the environment monitoring of the Guanabara bay.

\section{ACKNOWLEDGMENTS}

We are grateful to the team of the Laboratory of Marine Geology, Universidade Federal Fluminense (LAGEMAR/UFF) for the obtained sedimentological data, to Dr. Luciane G. Coelho (IBAMA) for the support with Tilia and Tilia Graph statistical programs, to Prof. Dr. Dorothy Sun Dun de Araújo for revising plant taxonomic and ecological data. Financial support: Conselho Nacional de Desenvolvimento Científico e Tecnológico (CNPq) and Coordenação de Aperfeiçoamento de Pessoal de Nível Superior (CAPES).

\section{RESUMO}

Com objetivo de investigar a deposição dos grãos de pólen e esporos na Baía de Guanabara, Estado do Rio de Janeiro, 61 amostras de sedimentos superficiais foram analisadas. Os resultados mostraram que a deposição atual dos palinomorfos nos sedimentos superficiais da Baía de Guanabara representa a vegetação regional de sua bacia hidrográfica. A distribuição diferencial dos palinomorfos seguiu um padrão influenciado pela batimetria, velocidade das corretes de marés, descarga dos numerosos rios e pela atividade humana. A dominância dos taxa representantes da Vegetação Campestre reflete as mudanças da flora original causadas por intensas atividades humanas na região. A presença contínua e a grande riqueza de tipos polínicos da Floresta Ombrófila nas amostras, indica que a área fonte pode ser a vegetação das bordas dos rios do setor oeste da Baía, onde a vegetação de mangue está sendo preservada. A grande quantidade de palinomorfos danificados pode estar relacionada ao desgaste que ocorre durante o transporte fluvial, indicando remoção ou retrabalhamento de suas áreas de origem.

Palavras-chave: palinomorfos, sedimentos superficiais, deposição, preservação, Baía de Guanabara, Brasil.

\section{REFERENCES}

AmAdor ES. 1992. Sedimentos de fundo da Baía de Guanabara - Uma síntese. In: III Congr Assoc Brasil Est Quaternário, p. 199-224. 
AMADOR ES. 1997. Baía de Guanabara e ecossistemas periféricos: homem e natureza. Edição do Autor, Rio de Janeiro, $539 \mathrm{p}$.

AMADOR ES AND PONZI VRA. 1974. Estratigrafia e sedimentação dos depósitos flúvio-marinhos da orla da Baía de Guanabara. An Acad Bras Cienc 46: 3-4.

ARAÚJO DSD AND MACIEL NC. 1979. Os manguezais do recôncavo da baía de Guanabara. Rio de Janeiro, Cadernos da Fundação Estadual de Engenharia do Meio Ambiente (FEEMA), Divisão de Comunicação e Treinamento, 60 p. (Série Técnica 10/79).

Baptista Neto JA, Gingele FX, Leipe T and Brehme I. 2006. Spatial distribution of heavy metals in surficial sediments from Guanabara Bay: Rio de Janeiro, Brasil. Environ Geol 45: 1051-1063.

BARRETO CF, BARTH OM, LUZ CFP, COELHO LG AND VILELA CG. 2006. Distribuição diferencial de palinomorfos na Baía de Guanabara, Rio de Janeiro, Brasil. Rev bras Paleontol 9(1): 15-24.

BARRETO CF, LUZ CFP, BAPTISTA-NETO JA, VILELA CG AND BARTH OM. 2007. Palynological analysis of a sediment core obtained in Guanabara Bay, Rio de Janeiro, Brazil. An Acad Bras Cienc 79: 223-234.

BARTH OM. 1972. Catálogo sistemático dos pólens das plantas arbóreas do Brasil Meridional - XIII. Flacourtiaceae e Caricaceae. Mem Inst Oswaldo Cruz 70: 1-13.

BARTH OM. 1976. Catálogo sistemático dos pólens das plantas arbóreas do Brasil Meridional - XXIII. Moraceae. Mem Inst Oswaldo Cruz 74: 295-309.

BARTH OM AND BARBOSA AF. 1972. Catálogo sistemático dos polens das plantas arbóreas do Brasil Meridional - XIV. Nyctaginaceae e Phytolaccaceae. Mem Inst Oswaldo Cruz 70: 241-267.

BARTH OM AND BARBOSA AF. 1975. Catálogo sistemático dos polens das plantas arbóreas do Brasil Meridional - XIX. Melastomataceae. Mem Inst Oswaldo Cruz 73: 39-60.

BARTH OM, BARRETO CF, COELhO LG AND LuZ CFP. 2004. Pollen record and paleoenvironment of a 4210 years B.P. old sediment in the Bay of Guanabara, Rio de Janeiro, Brasil. An Acad Bras Cienc 76: 549-551.

BARTH OM AND COSTA KMR. 1993. Catálogo sistemático do pólen das plantas arbóreas do Brasil Meridional - XXVI. Aquifoliaceae. Rev Bras Biol 53: 305-309.

BARTH OM, LuZ CFP, Toledo MB, Barros MA AND SILVA CG. 2001. "Palynological data from quaternary deposits of two lakes in the northern region of the State of Rio de Janeiro". In: Proceedings of the IX International Palynological Congress, Houston, Texas, USA, p. 443-450.

BEHLING H. 1995. Investigations into the Late Pleistocene and Holocene history of vegetation and climate in Santa Catarina (S Brazil). Veg Hist Archaeobot 4: 127-152.

BENNETT KD. 1986. Competitive interactions among forest tree populations in Norfolk, England, during the last 10.000 years. New Phytologist 103: 603-620.

Bove CP AND BARTH OM. 1992. Catálogo sistemático do pólen das plantas arbóreas do Brasil Meridional - XXV. Bignoniaceae. Rev Bras Biol 52: 283-292.
CAMPBELL ID. 1991. Experimental mechanical destruction of pollen grains. Palynology 15: 29-33.

COELHO LG, BARTH OM AND CHAVES HAF. 1999. O registro palinológico das mudanças de vegetação na região da Baía de Sepetiba, Rio de Janeiro, nos últimos 1000 anos. Leandra 14: 51-63.

DEBUSK GH. 1997. The distribution of pollen in the surface sediments of Lake Malawi, Africa, and the transport of pollen in large lakes. Rev Palaeobot Palynol 97: 123-153.

DENEMET. 1992. Normais climatológicas (1961-1990) Estação Aterro do Flamengo. Ministério da Agricultura e Reforma Agrária, Secretaria Nacional de Irrigação, Departamento Nacional de Meteorologia, Rio de Janeiro, Brasil.

DiAs GTM AND QuARESMA VS. 1996. Baía de Guanabara Evolução geomorfológica do fundo submarino. In: Congr Bras Geol 34, 1996. Anais, Salvador 4: 514-517.

FERRARI AL. 1990. A geologia do "rift" da Guanabara (RJ) na sua porção centro-ocidental e sua relação com o embasamento Pré-Cambriano. In: XXXVI Cong Bras Geol, Natal, RN, p. 2858-2872.

GARCIA MJ. 1997. Palinologia de turfeiras quaternárias do médio vale do rio Paraiba do Sul, Estado de São Paulo, Brasil. Parte 1: fungos, algas, Bryophyta e Pteridophyta. Rev Univ Guarulhos n. 2: 148-165.

GARCIA MJ. 1998. Palinologia de turfeiras quaternárias do médio vale do rio Paraíba do Sul, Estado de São Paulo, Brasil. Parte 2: Gymnospermae e Magnoliophyta. Rev Univ Guarulhos 3: 84-107.

GRIMM EC. 1987. Coniss: A Fortran 77 program for stratigraphically constrained cluster analisys by the method of the incremental sum of squares. Comput Geosci 13: 13-35.

GUEDES RR. 1988. Composição florística e estrutura de um trecho de mata pertubada de baixada no Município de Magé, Rio de Janeiro. Arq Jard Bot 29: 155-200.

GUY-OHLSON D. 1992. Botryococcus as an aid in the interpretation of palaeoenvironment and depositional processes. Rev Palaeobot Palynol 71: 1-15.

HooghiEMSTRA H. 1984. Vegetacional and climatic history of the high plain of Bogotá, Colombia: a continuous record of the last 3.5 million years. In: Van Der Hammen T (Ed), The Quaternary of Colombia, 10. J. Cramer, Amsterdam, 368 p.

IRELAND S. 1987. The Holocene sedimentary history of the coastal lagoons of Rio de Janeiro state, Brazil. In: Tooley MJ and Shennan I (Eds), Sea level changes. The Institute of British Geographers Special Publications Series, Basil Balckwell 20: 25-66.

JACKSON ST. 1990. Pollen source area and representation in small lakes of the Northeastern United States. Rev Palaeobot Palynol 63: 53-76.

JACOBSON GL AND BRADSHAW RHW. 1981. The selection of sites for paleovegetational studies. Quaternar Res 16: 80-96.

JICA. 1994. The Study on Recuperation of the Guanabara Bay Ecosystem. Supporting Report, Japan International Cooperation Agency (JICA), Kokusai Kogyo Co. Ltd. Tokyo, p. 1-4. 
KJerfye B, Ribeiro CH, Dias GTM, Filippo M AND QUARESMA VS. 1997. Oceanographic characteristics of an impacted coastal bay: baía de Guanabara, Rio de Janeiro, Brazil. Cont Shelf Res 17(13): 1609-1643.

LORSCHEITTER ML, ASHRAF AR, BUENO RM AND Mosbrugger V. 1998. Pteridophyte spores of Rio Grande do Sul flora, Brazil, Part I. Palaeontographica, Abt B 246: 1-113.

LORSCHEITTER ML, ASHRAF AR, WINDISCH PG AND Mosbrugger V. 1999. Pteridophyte spores of Rio Grande do Sul flora, Brazil, Part II. Palaeontographica. Abt B 251: 71-235.

LuZ CFP AND BARTH OM. 2000. Palinomorfos indicadores de tipos de vegetação em sedimentos holocênicos da Lagoa de Cima, norte do Estado do Rio de Janeiro, Brasil Dicotyledoneae. Leandra, (UFRJ) 15: 11-34.

LUZ CFP, BARTH OM AND MARTIN L. 1999. Evolução das florestas tropical estacional semidecidual e ombrófila densa durante o Holoceno Médio na região norte do Estado do Rio de Janeiro, baseado em palinologia. Geocienc 4(6): 74-84.

LUZ CFP, BARTH OM AND SILVA CG. 2005. Spatial distribution of palynomorphs in the surface sediments of the Lagoa do Campelo lake, North region of Rio de Janeiro State, Brasil. Act Bot Bras 19(4): 741-752.

Martin L, Suguio K, Dominguez JML, Flexor JM AND AzEvedo AEG. 1997. Geologia do Quaternário Costeiro do Litoral do Rio de Janeiro e do Espírito Santo. Belo Horizonte, FAPESP/CPRM, 112 p.

Moore PD, Weeb JA And Collinson ME. 1991. Pollen Analysis. Oxford, Blackwell scientific Publications.

RADAMBRASIL. 1983. Folhas SP. 23/24, Rio de Janeiro/Vitória; geologia, geomorfologia, pedologia, vegetação e uso potencial da terra. Rio de Janeiro: MME (sec. ger.) 32: 780.

RuELlan F. 1974. Evolução geomorfológica da Baía de Guanabara e das regiões vizinhas. Rev Bras Geogr 6: 445-508.

SALGADO-LABOURIAU ML. 2001. Reconstruindo as comunidades vegetais e o clima no passado. Humanidades, p. 24-40.

SANTOS DS, BARTH OM AND CHAVES HAF. 2000. Mudanças na vegetação do manguezal de Guaratiba, Estado do Rio de Janeiro, nos últimos 6.000 anos, baseado em palinologia. Geocienc 5: 156-159.
Stebich M, Brqchmann C, Kulbe T And Negendank JFW. 2005. Vegetation history, human impact and climate change during the last 700 years recorded in annually laminated sediments of Lac Pavin, France. Rev Palaeobot Palynol 133: 115-133.

STOCKMARR J. 1971. Tablets with spores used in absolute pollen analysis. Pollen et Spores 13: 615-621.

Sugita S. 1993. A Modelo f Pollen Source Area for an Entire Lake Surface. Quaternar Res 39: 239-244.

TOLEDO MB, BARRos MA AND BARTH OM. 1994. Contribuição a palinologia da lagoa Salgada, Rio de Janeiro. In: VIII Reunião de Paleobot Palinol, São Paulo. Resumos, 81 p.

Traverse A. 1994. Sedimentation of Organic Particles. Syndicate of the Universe the of Cambridge, New York, USA, $524 \mathrm{p}$.

TYSON RV. 1995. Sedimentary Organic Matter. Londres, Chapman and Hall, 614 p.

Veloso HP, RAngel Filho LR AND Lima JCA. 1991. Classificação da vegetação brasileira adaptada a um sistema universal. Publicação Inst Bras Geog (IBGE), Rio de Janeiro, RJ, Brasil, 124 p.

Vilela CG, SANJines AES, Ghiselli Jr RO, MendonçA Filho JG, BAPtista Neto JA AND BARbosa CF. 2003. Search for Bioindicators os pollution in the Guanabara Bay: Integrations of ecology patterns. An Inst GeociencUFRJ 26: 25-35.

WILMSHURST JM AND MCGLONE MS. 2005. Origin of pollen and spores in surface lake sediments: Comparison of modern palynomorph assemblages in moss cushions, surface soils and surface lake sediments. Rev Palaeobot Palynol 136: 1-15.

Ybert JP, SAlgado-Labouriau ML, BARTH OM, LORSCHEITTER ML, BARROS MA, CHAVES SAM, LUZ CFP, RIBEIRO M, SCHEEL R AND VICENTINI KRF. 1992. Sugestões para padronização da metodologia empregada para estudos palinológicos do Quaternário. Rev Inst Geol 13: 47-49. 